\title{
Equitable allowances or restitutionary measures for dishonest assistance and knowing receipt

\author{
DEREK WHAYMAN ${ }^{*}$
}

Lecturer in Law, Newcastle University

\begin{abstract}
This article considers the credit given to dishonest assistants and knowing recipients in claims for disgorgement, with greater focus on dishonest assistance. Traditionally, equity has awarded a parsimonious 'just allowance' for work and skill. The language of causation in Novoship (UK) Ltd v Mikhaylyuk [2014] EWCA Civ 908 suggests a more generous restitutionary approach which is at odds with the justification given: prophylaxis. This tension makes the law incoherent. Moreover, the bar to full disgorgement has been set too high, such that the remedy is unavailable in practice. Therefore, even if the restitutionary approach is affirmed, it must be revised.
\end{abstract}

Keywords: disgorgement; equitable allowances; remoteness of gain; dishonest assistance; knowing receipt.

$\mathrm{D}$ isgorgement in equity has become more widely available. It is familiar as against a fiduciary where the profits of the defaulting fiduciary's efforts are appropriated to the principal, seen in cases such as Boardman v Phipps. ${ }^{1}$ In Novoship (UK) Ltd v Mikhaylyuk, the Court of Appeal held that disgorgement is available in principle against accessories (meaning dishonest assistants and knowing recipients) to a breach of fiduciary duty. ${ }^{2}$ Disgorgement is used equivalently to account of profits in this article ${ }^{3}$ and is a gain-based remedy that takes net profit. ${ }^{4}$ The remedy against accessories is personal, not proprietary, but is not limited to the principal sum extracted, if any. The judgment appears to support a claim in principle for full account of profits, not limited to smaller measures such as the Wrotham Park 'hypothetical bargain'. ${ }^{5}$

* derek.whayman@newcastle.ac.uk.

1 [1967] 2 AC 46 (HL).

2 [2014] EWCA Civ 908, [2015] QB 499.

3 Peter Devonshire, Account of Profits (Thomson Reuters 2013) para 2.2 also argues they are equivalent. See also Paul Collins, 'Liability for Profits in Breach of Contract: Revisiting Attorney-General v Blake' [2015] RLR 44, 47 in n 32. Cf James Edelman, Gain-based Damages: Contract, Tort, Equity and Intellectual Property (Hart 2002) $72 \mathrm{ff}$. Edelman identifies a distinction where the account of profits, unlike disgorgement, would include costs avoided. English law is sceptical of such a claim: A-Gv Blake (Jonathan Cape Ltd Third Party) [2001] 1 AC 268 (HL) 286.

4 There are other gain-based measures: see James Edelman, 'Restitutionary Damages and Disgorgement Damages for Breach of Contract' [2000] 2 Restitution Law Review 129 for a taxonomy.

5 Wrotham Park. Estate Co Ltd v Parkside Homes Ltd [1974] 1 WLR 798 (Ch). 
In Novoship, the Court of Appeal decided upon a primary test of 'effective causation' to decide whether to disgorge an accessory's gain or not; asking whether the gain would have been made 'but for' the wrong was not appropriate. Gain 'effectively caused' by the wrongdoing would be disgorged, otherwise it would be credited to the wrongdoer's own legitimate efforts. In addition, there is a discretion whether to disgorge or not and disgorgement will not be ordered if it would be disproportionate to do so. ${ }^{6}$ Causation is the language of restitution for wrongs; ${ }^{7}$ contrast this with the traditional language of permitting a 'just allowance' in the breach of fiduciary duty cases. ${ }^{8}$

Where there is disgorgement, a question always follows: is the wrongdoer permitted to retain any of the gain? And if so, why and how is it measured? As Virgo points out, such questions of assessment have received insufficient attention in both cases and commentary. ${ }^{9}$ Given the expansion of the jurisdiction to disgorge, these questions are especially due for fresh examination. Ultimately, it comes down to this: should we give accessories a generous, or parsimonious, allowance? And, having made that choice, what is the appropriate conceptual framework and language and, indeed, what, if any, is the difference between restitutionary and traditional equitable approaches? These are the questions this article attempts to answer.

This article takes the position that there is a difference in balance between the two approaches. Restitutionary approaches are often more generous, tending to allow profitsharing, where the traditional equitable approach is more parsimonious, tending to allow only remuneration for work and skill expended. Moreover, two specific differences are identified. Both were in point in Novoship.

The first is the treatment of external or neutral events such as market movements. The equitable approach would exclude them from an allowance where restitutionary approaches may not. The second is that the court held that if the principal forgoes an opportunity and the dishonest assistant takes it, disgorgement of the gain would be disproportionate and thus disallowed. This is not the case for fiduciaries.

This leads to a problem. The justification for disgorgement given in the judgment was the fiduciary one: the deterrence of (or prophylaxis against) wrongdoing. ${ }^{10}$ This is incongruous with the generosity of the tests. The problem is a lack of consistency and this makes the law difficult to apply and endangers its coherent development. It is argued that paying insufficient attention to the normative matters behind the tests adopted led to this problem.

Moreover, even if this generous approach is to be preferred, the tests adopted for disgorgement need refinement. By construing 'effective causation' so narrowly, the Court of Appeal appears to have unwittingly limited disgorgement to the hypothetical bargain measure, which arguably is not full-blown disgorgement at all. ${ }^{11}$

6 Novoship (n 2) [119].

7 E.g. Graham Virgo, 'Restitutionary Remedies for Wrongs: Causation and Remoteness' in Charles E F Rickett (ed), Justifying Private Law Remedies (Hart 2008); Peter Birks, An Introduction to the Law of Restitution (Clarendon 1989) $351 \mathrm{ff}$.

8 E.g. Lord Provost v Lord Advocate (1879) 4 App Cas 823 (HL Sc) 839. See generally J D Heydon, M J Leeming and P G Turner, Meagher, Gummow and Lehane's Equity: Doctrines and Remedies (5th edn, LexisNexis Butterworths 2014) para 5-280.

$9 \quad$ Virgo (n 7) 301.

10 Novoship (n 2) [73]-[77], [110]; Fiona Trust \& Holding Corporation v Privalov [2010] EWHC 3199 (Comm), (2011) 108 LSG 17 [66] both citing Consul Development Pty Ltd v DPC Estates Pty Ltd (1975) 132 CLR 373 (HCA) 397.

11 See e.g. Edelman (n 3) 2-3 and ch 3. 
Although a less generous approach is advocated, it is these two problems with which this article is primarily concerned. The level of generosity of allowances is a matter of opinion and the courts may differ in their opinion. However, the coherence and limitation points are matters of logic and principle. One cannot be generous and parsimonious at the same time.

This argument proceeds as follows. The justification for and the approaches for defining allowances and the terminology and how it has been applied in practice are set out. This enables a close analysis of Novoship, which brings out the aforementioned points. Finally, how the law could be refined is considered.

\section{The facts of Novoship}

In order to hang the discussion on some concrete facts - and because specific criticism of the case will be made - a brief outline of Novoship (UK) Ltd v Mikhaylyuk is necessary. Novoship was a case of dishonesty and corruption by one of Novoship's managers, one Mikhaylyuk, who stood in a fiduciary position to them. There were two corrupt transactions. The first concerned charters ostensibly between Novoship and Petroleos de Venezuela SA, which were arranged by Mikhaylyuk (the PDVSA transaction). In reality, one Ruperti was interposed between the two, overcharging PDVSA and paying bribes to a company called Amon, which was controlled by one Nikitin. Participating was clearly a breach of fiduciary duty by Mikhaylyuk. Nikitin knew that Mikhaylyuk had required bribes as the price of chartering Novoship's vessels. This made Nikitin a dishonest assistant in respect of this transaction.

The second concerned the 'Henriot transaction' from which the gain (some $\$ 109$ million) was sought. At the same time, Mikhaylyuk was arranging charters to Nikitin's other company, Henriot Finance. Nikitin spent his own money in this venture and paid as near to market rates for the head charters as mattered. ${ }^{12}$ However, this was still a breach of fiduciary duty on the part of Mikhaylyuk because of (at the very least) the realistic possibility he was putting his own interests ahead of Novoship's. As for Nikitin, he knew enough such that it was dishonest to enter into these charterparties, which made him a dishonest assistant in respect of this transaction too. Christopher Clarke J summed it up by remarking that Mikhaylyuk 'was continuing a relationship which was corrupt in inception and had not been cleansed'. 13

Nikitin's profit was largely due to the extraordinary rise in the market between the conclusions of the head charters and the sub-charters he entered into. What was sought was therefore the profit of the accessory, not that of the principal under some form of joint and several liability. Nikitin did not pay or receive bribes in respect of the Henriot transaction. ${ }^{14}$ However, there was a clear causal link to his wrongdoing - without the dishonest assistance in the PDVSA transaction, Nikitin could not have made the profit because he would not have been able to secure the head charters. ${ }^{15}$ This is referred to as the 'collateral advantage' Nikitin obtained.

The independent enterprise Nikitin ran, that of sub-chartering Novoship's vessels, was entirely legitimate, save that it was made possible by the corrupt relationship.

12 Novoship (n 2) [65].

13 Novoship (UK) Ltd v Mikhaylyuk [2012] EWHC 3586 (Comm) [509].

14 Novoship (n 2) [8].

15 Ibid [9]. 
Novoship had wished to charter the vessels at the then market rates in order to lay off the risk of market fluctuations. ${ }^{16}$ This was important to the Court of Appeal's reasoning. Nikitin escaped liability for two reasons. First, because the profit was caused, according to the Court of Appeal, 'effectively' by the shipping market's rise rather than the wrongdoing (Nikitin had been a skilful businessman and had judged the market well); ${ }^{17}$ and second, there was a discretion to refuse disgorgement and it would be exercised because it would have been disproportionate to disgorge given Novoship's desire to lay off the risk, ${ }^{18}$ or, in other words, because Novoship had actively declined the opportunity.

\section{Justifying disgorgement}

\section{2.a FIDUCIARIES}

First consider why disgorgement is justified. This article accepts the conventional justifications for the disgorgement remedy against fiduciaries: prophylaxis and deterrence. ${ }^{19}$ If there is a requirement to deter in all circumstances, there must be a remedy that does not depend on there being actual losses. Otherwise there would be no remedy if it is not possible to rescind a transaction (and have restitution of benefits) since there are no punitive damages in English equity. The familiar propositions as to the fiduciary rules follow. It does not matter that the principal suffered no loss: ${ }^{20}$ ' $[\mathrm{B}]$ etter the principal receive a windfall than that the fiduciary retain the profit. ${ }^{21}$ Equity will not allow a fiduciary to keep his or her wrongful gain pour encourager les autres. ${ }^{22}$

There are also principled accounts that justify disgorgement against fiduciaries for other reasons. For instance, Lionel Smith argues that a fiduciary is subject to a primary obligation to render any profit made in the relevant circumstances immediately to her principal and it is this that explains the rule that no loss is necessary. That primary obligation springs from the acquisition of part of the principal's autonomy when the fiduciary acquires legal powers to act on her behalf. ${ }^{23}$ Because this includes profit from activities that go against the principal's interest, often variants of the somewhat fictitious 'good man theory' are pressed into service. This holds that equity treats the wrongdoer as if he was acting on behalf of his principal all along. ${ }^{24}$

\section{2.b ACCESSORIES}

One principled justification for the disgorgement of accessories can be dismissed shortly. Lionel Smith's autonomy argument requires a pre-existing fiduciary relationship, but accessories are not fiduciaries. ${ }^{25}$ Since that relationship is absent, one might fix dishonest

16 Ibid [117].

17 Ibid [114].

18 Ibid [120].

19 E.g. Harris v Digital Pulse [2003] NSWCA 10, (2003) 197 ALR 626 [307]; Bank of Ireland v Jaffery [2012] EWHC 1377 (Ch), [287], quoting John McGhee, Snell's Equity (32nd edn, Sweet \& Maxwell 2010) para 7-018.

20 Keech v Sandford (1726) Sel Cas Ch 61, 25 ER 223; Regal (Hastings) Ltd v Gulliver [1967] AC 134, [1942] 1 All ER 378 (HL); Boardman v Phipps (n 1).

21 Lord Peter Millett, 'Bribes and Secret Commissions Again' (2012) 71 Cambridge Law Journal 583, 600.

22 Murad v Al-Saraj [2005] EWCA Civ 959, [2005] WTLR 1573 [74]; Warman International Ltd v Duyyer (1995) 182 CLR 544 (HCA) 562.

23 Lionel Smith, 'Fiduciary Relationships: Ensuring the Loyal Exercise of Judgement on Behalf of Another' (2014) 130 Law Quarterly Review 608.

24 Sir Peter Millett, 'Bribes and Secret Commissions' [1994] Restitution Law Review 7, 20; A-G for Hong Kong v Reid [1994] AC 324 (PC).

25 Williams v Central Bank of Nigeria [2014] UKSC 10, [2014] AC 1189. 
assistants and knowing recipients with liability to disgorge through the principles of conventional accessorial liability. This would, however, make the accessory's liability duplicative of the fiduciary's, i.e. the accessory would be liable for the fiduciary's gain, not his own. ${ }^{26}$ This proposition has been rejected in the case law. In Ultraframe (UK) Ltd v Fielding, Lewison $\mathrm{J}$ was concerned that holding a dishonest assistant liable to disgorge profits made by the trustee directing the breach was 'begin[ing] to look like a punitive measure'. ${ }^{27}$ The Court of Appeal was also concerned that the remedy was not fashioned as a form of forfeiture in Novoship. ${ }^{28}$

Since the liability is for the accessory's own profits, it can only be independent or primary liability. ${ }^{29}$ Ridge, considering dishonest assistance, argues that disgorgement can be justified as simply the appropriate remedy for a wrong. ${ }^{30}$ Disgorgement is appropriate where the level of the accessory's culpability or closeness to the fiduciary warrants it. An example Ridge gives is the active and deliberate encouragement of the breach of fiduciary duty by the dishonest assistant. ${ }^{31}$ The justifications (or 'pragmatic grounds') Ridge gives are: (i) an alternative claim in the event that the fiduciary is impecunious or has absconded; and (ii) the deterrence of third parties. ${ }^{32}$ The first is applicable only to claims for compensation, so that leaves only the second for claims for disgorgement.

According to the Court of Appeal in Novoship, the principle of deterrence applies to accessories as well as fiduciaries. The court endorsed dicta in Consul Development Pty Ltd v DPC Estates Pty Ltd holding that:

If the maintenance of a very high standard of conduct on the part of fiduciaries is the purpose of the rule it would seem equally necessary to deter other persons from knowingly assisting those in a fiduciary position to violate their duties. ${ }^{33}$

Although the court left open the choice between that and the other justification in Consul Development, namely that it would be 'inequitable' to allow the accessory to retain the profit, this is hardly a reasoned justification. Deterrence was the only substantive reason given. ${ }^{34}$

Consequently, the only basis to support disgorgement claims against accessories is that of deterrence. It follows that, if fiduciary prophylactic principles are to be applied to accessories, then the law should not take into account whether the principal suffered a loss or whether the principal would gain a windfall. The culpability of the accessories should, however, matter.

It also follows that knowing recipients should perhaps be treated differently to dishonest assistants. Knowing receipt may not warrant full disgorgement or disgorgement

26 Steven B Elliott and Charles Mitchell, 'Remedies for Dishonest Assistance' (2004) 67 Modern Law Review 16, 17.

27 [2005] EWHC 1638 (Ch) [1597]-[1601], quoting Elliott and Mitchell (n 26) 41.

28 Novoship (n 2) [116] quoting Murad v Al-Saraj (n 22) [85]: 'The kind of account ordered in this case is an account of profits, that is a procedure to ensure the restitution of profits which ought to have been made for the beneficiary and not a procedure for the forfeiture of profits to which the defaulting trustee was always entitled for his own account.'

29 In this sense the term 'accessory' can be criticised as a misnomer: Sarah Worthington, 'Exposing Third Party Liability in Equity: Lessons from the Limitation Rules' in Paul S Davies and James Penner (eds), Equity, Trusts and Commerce (Hart 2017) (forthcoming) 'Conclusion', point 3. However, dishonest assistance and knowing receipt liability is founded on an underlying breach of trust or fiduciary duty, so these wrongdoers are accessories to a primary wrong in that sense.

30 Pauline Ridge, 'Justifying the Remedies for Dishonest Assistance' (2008) 124 Law Quarterly Review 445, 446.

31 Ibid 455.

32 Ibid 446.

33 Novoship (n 2) [76] quoting Consul Development v DPC (n 10) 397.

34 In Fiona Trust (n 10) [66], Andrew Smith J did not choose one basis over the other either. 
at all because there will always be a loss to sue for - the value of the property received. This is not necessarily the case for dishonest assistance.

\section{Justifying allowances}

\section{3.a FIDUCIARIES}

Once disgorgement is justified, the question is: how much? There is a countervailing principle to disgorgement against fiduciaries: non-forfeiture. While disgorgement clearly has a punitive element, ${ }^{35}$ it is not forfeiture sensu stricto. It is said that 'equity never forfeits' ${ }^{36}$ In fiduciary cases, liability is limited either to the fiduciary's actual net profits (if any), ${ }^{37}$ to what the principal ought to have received, ${ }^{38}$ or to actual losses. ${ }^{39}$ In Vyse $v$ Foster the Court of Appeal said that ' $[t]$ his Court is not a Court of penal jurisdiction'. ${ }^{40}$

While these two principles are clearly in tension, the one uncontroversial point is that disgorgement is of net profits. Legitimate expenditure is always deducted, hence the phrase 'account of profits'. It is a short stretch to make an allowance for work and skill expended by the wrongdoer, as this is little different to expenditure on a consultant to do the same. It is where this principle is carried forward that the controversy builds. It is clear that permitting the wrongdoer to share in the profits reduces the deterrent effect. And this leads to the well-known dictum of Lord Goff insisting that:

[T] he exercise of the jurisdiction [to award allowances must be] restricted to those cases where it cannot have the effect of encouraging trustees in any way to put themselves in a position where their interests conflict with their duties as trustees. $^{41}$

Nonetheless, as Harding points out, Lord Goff did not go so far as saying that allowances were never justified. Therefore, even on his strict view, some level of allowance is appropriate, ${ }^{42}$ even if it tends towards over-protection. Moreover, restricting allowances too severely would amount to forfeiture. In the recent case of Murad $v$ Al-Saraj, ${ }^{43}$ Arden LJ quoted concerns from the old case of Docker $v$ Somes. ${ }^{44}$ A hypothetical example was of a pharmacist who bought drugs with $£ 100$ of trust money and earned $£_{1000}$ selling them to patients. Lord Brougham suggested these were cases primarily of skilful labour that would not be subject to disgorgement. ${ }^{45}$ 'Full' disgorgement absent an allowance certainly appears to trespass into the realm of forfeiture in such cases.

That is as far as it goes. There are statements to the effect that:

35 Re Western of Canada Oil, Lands and Works Co (No 1), Carling's Case (1875) 1 Ch D 115 (CA), 123; David Stevens, 'Restitution, Property and the Cause of Action in Unjust Enrichment: Getting by with Fewer Things (Part 1)' (1989) 39 University of Toronto Law Journal 258, 279.

36 Gary Watt, 'Property Rights and Wrongs: The Frontiers of Forfeiture' in Elizabeth Cooke (ed), Modern Studies in Property Law Volume 1: Property 2000 (Hart 2001) 116. See also A-G v Alford (1854) 4 De GM \& G 843, 853; 43 ER 737, 742; Westdeutsche Landesbank Girozentrale v Islington London Borough Council [1996] AC 669 (HL), 692.

37 Vyse v Foster (1872) LR 9 Ch App 309 (CA Ch), 333.

38 Ibid; A-G v Alford (1854) 4 De GM \& G 843, 851; 43 ER 737, 741.

39 Brickenden v London Loan \& Savings Co [1934] 3 DLR 465 (PC); Swindle v Harrison [1997] 4 All ER 705 (CA).

40 Vyse v Foster (n 37) 333.

41 Guinness plc v Saunders [1990] 2 AC 663 (HL) 701. This must apply to all types of fiduciaries, not just trustees.

42 Matthew Harding, 'Justifying Fiduciary Allowances' in Andrew Robertson and Tang Hang Wu (eds), The Goals of Private Law (Hart 2009) 344.

43 Murad v Al-Saraj (n 22) [85].

44 (1834) 2 My \& K 655, 39 ER 1095.

45 (1834) 2 My \& K 655, 667; 39 ER 1095, 1099. 
[Equitable] remedies will be fashioned according to the exigencies of the particular case so as to do what is 'practically just' as between the parties. The fiduciary must not be 'robbed'; nor must the beneficiary be unjustly enriched. ${ }^{46}$

However, the limit of robbing the fiduciary appears to be set at the level of what would cause forfeiture. The dicta quoted above show that a windfall is not considered unwarranted enrichment provided it is given in the name of prophylaxis. ${ }^{47}$

\section{3.b ACCESSORIES}

Allowances for accessories - or indeed reasons for excusing the accessory from disgorgement altogether - would therefore be justified for at least the same reasons as for fiduciaries. The further reason is to reflect any lesser culpability on the part of the accessory. There are some justifications for treating accessories differently and they are examined here.

The distance of the accessory from the fiduciary relation was an important factor for the Court of Appeal in Novoship. ${ }^{48}$ It relied heavily on the Supreme Court case of Williams $v$ Central Bank of Nigeria where it was confirmed that accessories are not fiduciaries and the rules are less strict: 'No trust has been reposed in [the accessory]. ${ }^{49}$ A limitation period is applied to accessories where one is not to a trustee, at least in respect to the stewardship of trust property. ${ }^{50}$

However, that is just one factor. The difference in limitation period is justified by the fact that the trustee is entrusted with the long-term stewardship of property. The trustee's involvement in the trust's affairs is entirely to be expected and gives no grounds for suspicion without more. The accessory is typically not involved so closely and for such a long period of time and, as such, there is no excuse for excessive delay on the part of the beneficiary in taking action. ${ }^{51}$ But what justifies a shorter limitation period does not necessarily justify reduced liability in other areas.

Indeed, as the Court of Appeal said in Novoship, there is an imperative to deter fiduciary wrongdoing and its assistance, hence the accessory is also made liable. ${ }^{52}$ This suggests that the underlying norms are the same or similar even if the concrete rules have to be made different to reflect the accessory's different place in the scheme of things. Old dicta such as 'clothing [the] stranger . . . with the fiduciary character, for the purposes of making him accountable'53 can further be taken to reflect the courts' attitude that the norms are the same and the rules adopted must remain within the range of possibilities consistent with those underlying norms. ${ }^{54}$ If one is to take Lord Goff's dictum concerning deterring fiduciary breach ${ }^{55}$ seriously - or as seriously as is possible while still accepting a need for allowances - these matters need to form part of the discussion. They did not, however, in Novoship.

46 Maguire v Makaronis (1997) 188 CLR 449 (HCA), 496, quoted in Sinclair Investments (UK) Ltd v Versailles Trade Finance Ltd [2011] EWCA Civ 347, [2012] Ch 453 [47].

47 Section 2.a.

48 Novoship (n 2) [68]ff.

49 Williams v Central Bank of Nigeria (n 25) [31].

50 Ibid.

51 Ibid [13].

52 Novoship (n 2) [76] quoting Consul Development v DPC (n 10) 397.

53 Docker v Somes (1834) 2 My \& K 655, 665; 39 ER 1095, 1098.

54 A point also made by Virgo (n 7) $328 \mathrm{ff}$.

55 See text to $\mathrm{n} 42$ above. 


\section{Approaches to formulating liability and allowances}

\section{4.a NomenClature AND BALANCE}

The issue is then how to express in concrete rules the principles governing allowances and, indeed, whether there is liability - the two overlap, as will be seen when discussing restitutionary measures. Accordingly, this section is concerned with the terminology used and precisely what it means in order to address the questions of basis of disgorgement and allowance. There are two broad choices as to the principles governing measure of allowance, as Mason J states:

One approach, more favourable to the fiduciary, is that he should be held liable to account [only] of the particular benefits which flowed to him in breach of his duty. Another approach, less favourable to the fiduciary, is that he should be held accountable for the entire business and its profits, due allowance being made for the time, energy, skill, and financial contribution that he has expended or made. ${ }^{56}$

Theories of restitution do not preclude the possibility of adopting Mason J's latter approach. It is a crude caricature to say that restitutionary theories are an attempt to homogenise the rules for vastly different causes of action into a set of fixed rules. Indeed, Birks went so far as to argue that restitution for wrongs ought to be studied within the law of wrongs, not the law of unjust enrichment. ${ }^{57}$ He identified three broad classes of restitution for wrongs: (a) the deliberate exploitation of wrongdoing; (b) anti-enrichment, as opposed to anti-harm, wrongs; and (c) prophylaxis. ${ }^{58}$ While he did not consider quantum and allowances in respect of each class, his schema comfortably accommodates the possibility of different norms supporting disgorgement claims, putting fiduciary actions in category (c) and leaving space for more generous allowances in other actions. Furthermore, Virgo has argued that rules of causation and remoteness will have to be adapted with respect to 'the different policies underpinning particular wrongs'. ${ }^{59}$

This leads to the names proposed for each approach identified by Mason J. Since the prophylactic approach demands no profit is left with the wrongdoer, the first approach can conveniently be called 'non-prophylactic' and the second 'prophylactic'. Clearly, they are ends of a continuum and, in practice, giving an allowance may be a difficult and uncertain exercise in finding the balance.

\section{4.b EQUITABLE JUST ALLOWANCES}

Conventionally, equity has adopted the latter approach. Fiduciary allowances are discretionary ${ }^{60}$ and it is for the wrongdoer to establish that he should be granted an allowance. ${ }^{61}$ Perhaps the most significant factor is the blameworthiness of the wrongdoer. In Boardman v Phipps the worst of the fiduciary's behaviour towards the trust was perhaps insufficient disclosure and a liberal allowance was therefore permitted. ${ }^{62}$

56 Hospital Products Ltd v United States Surgical Corporation (1984) 156 CLR 41 (HCA), 110.

57 Peter Birks, Unjust Enrichment (2nd edn, Oxford University Press 2005); Peter Birks, 'Misnomer' in W R Cornish et al (eds), Restitution: Past, Present and Future: Essays in Honour of Gareth Jones (Hart 1998).

58 Birks (n 7) 326-33.

59 Virgo (n 7) 303. Virgo did not tackle accessories to a breach of fiduciary duty, most likely because that work predates Novoship and the matter would then have seemed relatively unimportant.

60 Lord Provost v Lord Advocate (n 8) 839.

61 Warman v Dwyer (n 22) 561.

62 Boardman v Phipps (n 1). 
Conversely, the defendant's dishonesty was said to be a reason to deny him an allowance in Murad v Al-Saraj. ${ }^{63}$

Even in the least culpable of all breaches of fiduciary duty - where the fiduciary has actually made a profit for the trust that could not always have been made otherwise - a profit share was not permitted: Boardman $v$ Phipps. ${ }^{64}$ The texts list only O'Sullivan $v$ Management Agency and Music Ltd as an example where profit-sharing was permitted. ${ }^{65}$ There, the Court of Appeal held that in exceptional circumstances there might be a small profit element in the allowance given to the fiduciary. ${ }^{66}$ However, this was consistent with a pre-breach agreement to share profits, which was knowingly agreed to by the claimant. Moreover, the court expressly stated that the allowance had been reduced because of the wrongdoing. ${ }^{67}$

There are other factors, ${ }^{68}$ but these are the most significant. They lean heavily towards keeping the allowance parsimonious, towards remuneration for skill rather than a share of the profits. Certainly, in Warman International Ltd v Dwyer, it was noted that the fiduciary's unauthorised profit had been 'carved out of the business' of the principal and profitsharing was therefore inappropriate. ${ }^{69}$ In that case it was also said to be inappropriate to allow profit-sharing if the fiduciary had exposed the principal's property to risk. ${ }^{70}$

\section{C RESTITUTIONARY LANGUAGE: CAUSATION AND REMOTENESS}

Fiduciary cases have eschewed the language of causation and remoteness of gain in favour of framing the issue as one of granting an allowance. While the editors of Meagher, Gummow and Lehane's Equity: Doctrines and Remedies dismiss recourse to these concepts as having 'no support in either the doctrines by or the practices of the courts [and dependent on] restitutionary theories of an a priori kind', ${ }^{71}$ the restitutionary theories are, at the very least, a useful comparator. Moreover, that passage was apparently written before the judgment in Novoship was handed down and certainly without reference to it.

Causation encompasses more than a simple connection to the wrongdoing. How causation is drawn defines the kind of link required. It may be thought that, at a minimum, 'but for' causation is required: that the wrongdoer would not have made the same profit in a way other than via breach of duty. This is certainly what is apparently required in theories of restitution for wrongs derived from non-fiduciary cases. ${ }^{72}$ In the

63 Murad v Al-Saraj (n 22).

64 Boardman v Phipps (n 1).

65 [1985] QB 428 (CA): Heydon et al (n 8) para 5-280; Lynton Tucker, Nicholas Le Poidevin and James Brightwell, Lewin on Trusts (19th edn, Sweet \& Maxwell 2015) para 20-049; McGhee (n 19) para 7-027; Graham Virgo, The Principles of the Law of Restitution (3rd edn, Oxford University Press 2015) 436; Robert Pearce and Warren Barr, Pearce and Stevens' Trusts and Equitable Obligations (6th edn, Oxford University Press 2015) 884-5.

66 O'Sullivan (n 65) 462, 469. In Australia, profit-sharing is more likely to be granted: e.g. Warman v Dwyer (n 22).

67 O'Sullivan (n 65) 468.

68 See Heydon et al (n 8) para 5-280.

69 Warman v Dwyer (n 22) 568.

70 Ibid 561.

71 Heydon et al (n 8) para 5-280, but see Warman v Dwyer (n 22) 561 for a tentative move towards the language of causation, which the authors begrudgingly note. There are two possible explanations for this. First, it could simply be that equity has been slow to adopt these principles, but recent cases are challenging this reticence. For causation: breach of fiduciary duty: Brickenden ( $\mathrm{n}$ 39), cf Swindle v Harrison (n 39). Breach of trust: Re Dawson [1966] 2 NSWR 211 (New South Wales Supreme Court), cf Target Holdings Ltd v Redferns [1996] 1 AC 421 (HL). Second and related, it could be, as Edelman says, that these principles are in there infancy and have not yet been fully explored: Edelman (n 3) 103.

72 E.g. Virgo (n 7) 304. 
patent infringement case of Celanese International Corporation v BP Chemicals Ltd, the award was for the additional profits resulting from the infringement, rather than a complete account because " $\mathrm{t}$ ] he question to be answered is "what profits were in fact made by the defendant by the wrongful activity?". ${ }^{73}$ Implicit in this is that the defendant would have been able to make and market the product in any event, and should be credited for those hypothetical profits.

Celanese International also suggests that causation goes to quantum as well as liability. It also suggests that, for this cause of action, the measure of disgorgement looks to the part of the gain caused by the wrongdoing and omits the part not so caused. Fiduciary cases have rejected causation as a requirement. In Murad $v$ Al-Saraj, the fiduciary breached his fiduciary duty by failing to disclose that his contribution to a joint venture was by way of set-off rather than directly. ${ }^{74}$ Nonetheless, it was found that his co-venturers would have continued in any event and would merely have demanded a greater share of the profits. The Court of Appeal, by a majority, rejected the submission that the fiduciary should be granted an allowance accordingly, meaning a 'but for' link to the profit was not required. ${ }^{75}$ Instead, as Harding points out, the causal enquiry in fiduciary cases has been to seek a 'basic factual connection between $\ldots$ breach and $\ldots$ profit'. ${ }^{76}$

Nonetheless, fiduciary disgorgement cases have tended to insist on a degree of sufficiency of connection. This is captured in language such as 'Did [the defendants] ... acquire] these very profitable shares . . . in course of their office of directors? 77 But most often it is proximity. This can be seen as a bar to cases where the wrongdoing was of minimal effect but not cases where the wrongdoing is one of several causes of the profit. Moreover, there seems no reason why this kind of apportionment ought not to flow from both the 'but for' and sufficiency aspects of causation.

Remoteness of gain is also concerned with cutting off recovery, but with reference to different factors, often the time since the wrongdoing and where the profit arises from different facts. ${ }^{78}$ If I make an unlawful gain from my involvement in a car-maker and invest that gain in another completely independent business making bicycles, there is an argument that that second gain is due to my own efforts, even if I did not have the money otherwise (so the 'but for' causal link is made out). As Virgo points out, remoteness is concerned to prevent the over-protection of the principal. ${ }^{79}$

Although there is only limited support for them in the authorities, ${ }^{80}$ the tests postulated for remoteness serve well to illustrate the point. Birks' proposal was to limit recoverable gains to the 'first non-subtractive receipts' 81 (or, as Virgo puts it, gains arising 'directly from the commission of [the] wrong'). ${ }^{82}$ The profits from subsequent reinvestment of the gains would not be subject to disgorgement. An alternative proposal

73 [1999] RPC 203 (Ch) [39] (emphasis added).

74 Murad v Al-Saraj (n 22).

75 Similarly Industrial Development Consultants Ltd v Cooley [1972] 1 WLR 443 (Birmingham Assize) 453.

76 Harding (n 42) 345.

77 Regal (Hastings) (n 20) 145. See also Maguire v Makaronis (n 46) 468: 'sufficient connection' (or 'causation'); Warman v Dwyer (n 22) 557: 'necessary connection'; Visnic v Sywak [2009] NSWCA 173, [1]-[2].

78 See e.g. Birks (n 7) 351ff; Mysty S Clapton, 'Gain-based Remedies for Knowing Assistance: Ensuring Assistants Do Not Profit from their Wrongs' (2008) 45 Alberta Law Review 989, 1002; Murad v Al-Saraj (n 22) [79] commenting on Warman v Dwyer (n 22).

79 Virgo (n 7) 305.

80 Ibid $306 \mathrm{ff}$.

81 Birks (n 7) $351 \mathrm{ff}$.

82 Virgo (n 65) 436. 
is Edelman's, which is that an innocent wrongdoer be stripped of gains if there was a 'reasonable foreseeability of that kind of profit'.83 Deliberate or cynical wrongdoing should not attract such a limit, in accordance with the law's focus on culpability.

What these tests show is that, while there is a normative element in sufficiency of causation, it becomes much more explicit in questions of remoteness, as these tests show. The profit from the bicycle business was still caused factually by the wrongdoing, even if one considers the most effective cause to be my own efforts. If I am excused from disgorgement, it is for a normative reason such as preventing over-protection. Such norms can form part of either a causation test or a remoteness test, although they may be better suited to one over the other.

\section{4.d THE CONCEPTUAL VIEW: SIMILARITIES}

Ultimately, reconciling the principles governing liability and allowances comes down to the same fundamental issue: disgorging what is deemed to be due to the wrongdoing and permitting the wrongdoer to keep what is deemed due to the wrongdoer's own efforts. The word 'deemed' disguises two factors. The first is the normative justification for what is taken and what may be retained. The second is the set of specific rules adopted to determine the same.

In the context of compensation for loss, the overlap between causation and remoteness has long been acknowledged. ${ }^{84}$ Indeed, in recent times such doctrines governing loss have been conceptualised as mere expressions of the scope of duty or responsibility, most notably in the jurisprudence of Lord Hoffmann concerning causation, remoteness of loss and the implication of terms. ${ }^{85}$ Getzler highlights Lord Hoffmann's reflective point in South Australia Asset Management Corporation v York Montague $L t d$ that causation 'is deeply affected by the court's normative judgment of the purpose and the context of the duty whose breach is said to have caused the harm' ${ }^{86}$ Similarly, Stapleton notes that:

$[T]$ he reasoning in these decisions is obscured because it is couched in such causal formulations... The issue for the courts ... is a normative one and as such it is more conveniently posed in completely non-causal terms. ${ }^{87}$

Mitchell points out that the same applies 'with equal force to claims for unauthorised fiduciary gains' ${ }^{88}$ It is a short reach to further generalise Stapleton's proposition to orther gains claims. The importance and centrality of the normative foundation of the matter underpins Barker's observations about why one must use caution in adopting the language and principles from the doctrines limiting loss in tort and contract. He points out that the foreseeability test for remoteness of loss is justified by two reasons: (i) a moral objection to making a defendant liable for all losses caused because of the limits of human foresight; and (ii) the economic argument that the defendant is the cheapest loss-avoider

83 Edelman (n 3) 108-9.

84 E.g. Roe v Minister of Health [1954] 2 QB 66 (CA), 85.

85 Remoteness of loss: Transfield Shipping Inc v Mercator Shipping Inc (The Achilleas) [2008] UKHL 48, [2009] 1 AC 61; causation: South Australia Asset Management Corporation v York. Montague Ltd (S AAMCO) [1997] AC 191 (HL); implication: A-G of Belize v Belize Telecom Ltd [2009] UKPC 10, [2009] 1 WLR 1988.

86 Joshua Getzler, 'Equitable Compensation and the Regulation of Fiduciary Relationships' in Peter Birks and Francis Rose (eds), Restitution and Equity: Resulting Trusts and Equitable Compensation (Mansfield Press 2000) 245. See SAAMCO (n 85) 212-22.

87 Jane Stapleton, 'Cause in Fact and the Scope of Liability for Consequences' (2003) 119 Law Quarterly Review 388,422 .

88 Charles Mitchell, 'Causation, Remoteness, and Fiduciary Gains' (2006) 17 King's College Law Journal 325, 337. 
and thus the claimant is incentivised to protect him or herself from harms that might flow from the loss. As he says, these matters are not relevant to gains claims. ${ }^{89}$ Consequently, the rules are likely to be different and must be attuned to their (different) justifications.

The characterisation of the enquiry as determining the scope of the duty is too nebulous to yield concrete rules of law and the courts have drawn back from such generalities in favour of specific tests in recent leading cases concerning remoteness of loss, construction and the implication of terms in fact. ${ }^{90}$ Even so, the 'scope of duty' analysis yields one vital point: the underlying principles governing liability and quantum are normative in character.

The specific rules may well describe the precise responsibility of the wrongdoer accurately. They then give the law's norms 'concrete legal embodiment'. ${ }^{91}$ But those rules do not always fully describe the operation of the law. Sometimes one must rely on the 'justificatory and explanatory' function, as MacCormick puts it, ${ }^{92}$ of the underlying norm to inform the rule. So we have tests of 'effective causation' and 'proportionality' but they are only one part of the picture. They can only be understood and interpreted properly given the underlying norm. An underlying norm of prophylaxis suggests a broad construction of what was effectively caused by the wrongdoing and that there is no need for the principal to have suffered loss nor to have lost an opportunity. Conversely, an underlying non-prophylactic norm suggests a narrower construction and that loss, or a lost opportunity, is a requirement.

It therefore follows that both the particular formulations of the rules and their justifications must be carefully formulated in accordance with whatever standards the law declares its desire to uphold. It further follows that there is a requirement of coherence - the rules and their justifications must be consistent in aim. ${ }^{93}$ If they are not, the law will become impossible to apply with any certainty or to understand or develop consistently.

\section{4.e DIFFERENCES IN POINT}

For many cases there will not be much of a difference in outcome between approaches. Both can accommodate remuneration and profit-sharing; indeed, neither appears inherently limited to one or the other. We may quibble about the balance, but a significant and apposite point of departure is where one of the concurrent causes of the profit is attributable neither to the wrongdoer, the wrongdoing, nor the party to whom the duty is owed. Working through such circumstances demonstrates not only this, but also how the construction of 'effective causation' is determined by its underlying norms.

Such external causes may be due to a third party's intervention. This will usually be an intervention at the behest of the primary wrongdoer, in which case the cause can be attributed to the wrongdoer. Thus, the case of a third party is unlikely to be difficult. In practice another perennial problem is likely to yield a truly external cause: market movements.

89 Kit Barker, 'Riddles, Remedies, and Restitution: Quantifying Gain in Unjust Enrichment Law' (2001) 54 Current Legal Problems 255, $291 \mathrm{ff}$.

90 The restriction on The Achilleas (n 85) in Siemens Building Technologies FE Ltd v Supershield Ltd [2010] EWCA Civ 7, [2010] 2 All ER (Comm) 1185; Arnold v Britton [2015] UKSC 36, [2015] AC 1619 drawing back from Chartbrook Ltd v Persimmon Homes Ltd [2009] UKHL 38, [2009] 1 AC 1101; and Marks and Spencer plc v BNP Paribas Securities Services Trust Co (Jersey) Ltd [2015] UKSC 72, [2016] AC 742 drawing back from Belize Telecom (n 85) respectively.

91 Neil MacCormick, Legal Reasoning and Legal Theory (Clarendon 1994) 154-5.

92 Ibid 152 (emphasis added).

93 Ibid $152 \mathrm{ff}$. 
This was an issue in Novoship. It was the extraordinary rise in the shipping market that had generated the bulk of Nikitin's vast profit, at least numerically. The Court of Appeal was clear about what it considered the dominant cause of the gain: 'The real or effective cause of the profits was the unexpected change in the market. ${ }^{94}$ The vivid colloquialism 'real' makes it clear that this was a normative judgment.

It is here where the distinction between the two approaches to allowances is at its sharpest. The prophylactic approach, looking to the wrongdoer's legitimate work and skill put in, would not take market movements as part of this and allow disgorgement accordingly. It would disregard the fact that the claimant lost nothing or was uninterested in the opportunity. In effect it says that this part of the profit was not caused by the wrongdoer because it was part of the opportunity and, since the wrongdoer may only retain the profits he caused, he cannot retain these profits.

The non-prophylactic approach would, however, do the opposite. It would look to what was taken from the claimant - in this case nothing. Consequently, it would attribute gains arising from the market movements to the wrongdoer's legitimate work and skill. In effect it says that this part of the profit was caused by the wrongdoer and, since the wrongdoer may retain the profits he caused, he may retain these.

If the gains are extraordinary - as they were in Novoship - the difference in approaches will be enormous. The underlying norms matter.

\section{Analysis of Novoship}

With all this in mind, it is possible to take a close look at Novoship v Mikhaylyuk and particularly the meaning and ramifications of the adoption of the tests of effective causation and proportionality. The analysis is technical. However, it follows a relatively simple path at a high level of generality. Having established that:

1. the low-level rules adopted are an expression of the norms and general principles governing liability;

2. this particularly applies to causation and remoteness; and

3. accessories ought to be subject to disgorgement where appropriate;

The analysis continues:

4. the Court of Appeal paid insufficient attention to those norms per se;

5. the court did not engage in sufficient consequential reasoning to identify the difficulties the tests adopted would cause more generally; and

6. the court did not consider apportionment, with the result that:

7. the tests adopted were generous by any standards;

8. particularly, they take into account what the principal lost rather than considering only what the wrongdoer gained;

9. this is in tension with the justification given - prophylaxis - which looks not to what the principal lost but to what the wrongdoer gained; and

10. quantum appears limited to the Wrotham Park 'hypothetical bargain' measure, something closer to compensation than disgorgement.

Finally, a solution to the problem of dividing Nikitin's gain, necessary if one believes that partial disgorgement was appropriate, is advanced.

94 Novoship (n 2) [114]. 


\section{5.a ReMOteness AND (EFFECTIVE) CAUSATION}

'Effective causation' was not said to be a remoteness of gain test in Novoship, but it has some elements of remoteness in it. Saying that the profits from the Henriot transaction were effectively caused by other matters is in effect saying that they were too improximate from the wrongdoing. The risks of not adverting to the normative matters more explicit in remoteness are noted by Mitchell, building on Stapleton. Framing the question in terms of remoteness 'explicitly require[s] the court to assess whether or not imposing liability is fair and in accordance with the principles underlying the rules that give the claimant his cause of action'. ${ }^{95}$ But:

In contrast, the causation question asks the court whether the facts of a case possess some apparently freestanding analytical characteristic - 'Was the causal chain broken by an intervening event?' - a question which it is tempting for the court to answer without explicitly discussing the reasons why the answer matters. ${ }^{96}$

While the Court of Appeal did engage with normative matters, it did so mostly while applying the proportionality test. However, since both tests have to be met in order for there to be disgorgement, the normative matters ought to have been part of the discussion of what amounts to effective causation too. Yet the Court of Appeal applied the test as though it was a simple formula looking to the most effective cause.

\section{5.b UNCERTAINTY AS TO THE REQUIREMENT FOR 'BUT FOR' CAUSATION}

The test of 'effective causation' was taken from Galoo Ltd v Bright Grahame Murray. ${ }^{97}$ It can be traced back from that case to Monarch Steamship Co Ltd v Karlshamns Oljefabriker $(A / B) .{ }^{98}$ These are common law contract cases. For an award of compensation, the courts require not just a 'but for' connection between breach of contract and loss, but a degree of sufficiency too, that the breach was an 'effective cause' of the loss. In Monarch Steamship, much was made of the 'dominant' cause of the delay in delivery being the vessel's unseaworthiness rather than ship's requisition by the government for war purposes. According to the Supreme Court in AIB Group (UK) plc v Mark Redler \& Co Solicitors, there is no objection to borrowing principles from the common law and applying them to equitable actions, provided one is alive to the differences and is not blinded by the similarities. ${ }^{99}$

Before considering the norms behind 'effective causation', consider the requirement for 'but for' causation. While the Court of Appeal acknowledged that the trial judge had disavowed the need for a 'but for' link, ${ }^{100}$ it expressed disagreement with him at a rather more general level, namely that 'the same considerations that apply to a fiduciary [do not] apply to a dishonest assistant who has no fiduciary duties'. ${ }^{101}$ But rather than expressly admit or reject (i) a 'but for' test and (ii) a sufficiency test ('effective causation') distinctly, the Court of Appeal only went so far as to admit the latter and did not decide the former. ${ }^{102}$ Saying 'in our judgment the simple "but for" test is not the appropriate test'103

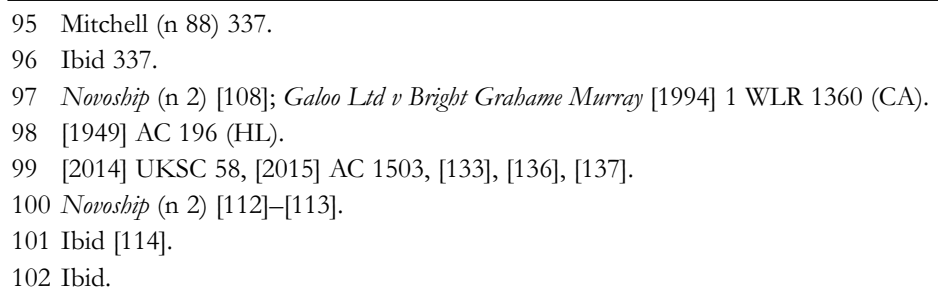


does not distinguish between whether it is one of a set of two tests (it alone is not the appropriate test), or it forms no part of the set of tests (it is inappropriate to consider it at all). The court's conclusion is equally unilluminating: the claim should be denied because 'there was an insufficient direct causal connection between entry into the Henriot charters [or transaction] and the resulting profits.' ${ }^{104}$

It is submitted that 'but for' causation should not be required. Generally, prophylactic remedies do not require this because deterrence demands a remedy for even a slight connection to the wrong. Even in a loss claim, dishonest assistance requires only a very weak causal connection, namely that some assistance was provided. ${ }^{105}$ 'But for' causation is not required in fiduciary disgorgement claims. It should therefore not be required either for non-fiduciary disgorgement claims where the justification is also prophylaxis.

\section{5.c Construing 'effective causation'}

The next issue is how widely 'effective causation' should be construed. In the common law compensation for breach of contract case of County Ltd $v$ Girozentrale Securities, it was decided that the offending act only needs to be 'an' effective cause. ${ }^{106}$ It was held that the court is not required to choose the most effective cause and is not constrained to decide there is liability only if that was the defendant's act or omission. Conversely, in Novoship the effectiveness requirement was construed narrowly; the market movements were more effective and that was the end of it.

Owing to the factual peculiarities of claims for disgorgement for dishonest assistance, this issue will come up generally. To see this, consider how a dishonest assistant's acts would be evaluated by an effective causation test. If a dishonest assistant receives a fee in return for assisting a fiduciary in a breach of fiduciary duty, it would be tolerably clear, on any principle of causation, that such 'profit' will have been caused by the dishonest assistance. But many dishonest assistants - such as a bribe-giver who pays in order to secure some advantage - will never make any profit unless he or she engages in an enterprise separate from the primary wrongdoing. ${ }^{107}$ Such a dishonest assistant must, however, receive some kind of collateral advantage otherwise there would be no incentive to act. This is illustrated by the facts of Novoship. Without participating in Mikhaylyuk's dishonest scheme, Nikitin would not have been able to charter Novoship's vessels in the first place.

This issue was touched on in OJSC Oil Company Yugraneft $v$ Abramovich, where it was intimated that the proceeds of the reinvestment of an initial gain might be subject to disgorgement from a dishonest assistant. ${ }^{108}$ That principle surely applies, mutatis mutandis, to the exploitation of a non-pecuniary gain. Abramovich was cited in Novoship, but not in relation to this issue. ${ }^{109}$ Yet Abramovich suggests that the law must be tailored such that some remoter gains are subject to disgorgement.

Indeed, given that the Court of Appeal said the action was available in principle, there must be some circumstances where it is in fact. It is unlikely that the court would have declared this remedy available only to make it otiose. It must therefore be necessary to

\footnotetext{
103 Ibid.

104 Ibid [115].

105 Grupo Torras SA v Al-Sabah (No 5) [2001] CLC 221 (CA) [119].

106 [1996] 3 All ER 834 (CA), 849, 857.

107 A point made in the court below: Novoship (HC) (n 13) [494].

108 [2008] EWHC 2613 (Comm) [392].

109 Novoship (n 2) [71].
} 
construe 'effective causation' widely in order for it to have any meaning at all in dishonest assistance cases and, certainly, it should encompass gains caused by such collateral advantages.

Yet the Court of Appeal construed it very narrowly. Accordingly, it would have been better if the test had been called 'dominant causation'. 110 And in dishonest assistance cases, where it is not necessary for the accessory to receive property, such profits will inevitably be predominantly caused by the wrongdoer rather than the wrongdoing. Therefore, as construed, 'effective causation' is very much a principle of the nonprophylactic approach, since it attributes such causes to the wrongdoer's own efforts. Conversely, if 'effective causation' were backed by prophylactic norms, it would attribute all but the ineffective causes to the wrongdoing.

\section{5.d THE PROPORTIONALITY TEST AND LACK OF APPORTIONMENT}

Consider now the proportionality test. It was introduced and applied under the broad consideration that the court has a discretion over whether to award an account of profits or not in claims against accessories. ${ }^{111}$ The Court of Appeal's reasoning was limited to noting that the remedy is discretionary in the non-fiduciary actions of breach of confidence ${ }^{112}$ and breach of contract ${ }^{113}$ and approving the proposition in Fyffes Group Ltd $v$ Templeman that an account of profits is not automatically awarded upon making out liability against an accessory to a breach of fiduciary duty. ${ }^{114}$

The judgment in Fyffes considered only breach of confidence cases in respect of this point. ${ }^{115}$ Toulson $\mathrm{J}$ refused a full account of profits because he had found that Fyffes would have entered into the relevant agreement even if the agent had not been dishonest. ${ }^{116}$ It was not that full disgorgement was said to be disproportionate, but full disgorgement was inappropriate because of consent to the profit element demonstrated by the antecedent profit-sharing arrangement. Hence, the reasoning takes in similar factors to those falling under the proportionality test in Novoship. However, Toulson J considered that they were relevant to quantum.

The possibility of apportionment was noted above, when discussing Celanese International. ${ }^{117}$ There are other cases too. In Seager $v$ Copydex (No 2), only a 'springboard' or 'headstart' measure was awarded for the inadvertent use of confidential information, meaning a measure of the advantage gained, namely a reduction in the development work owing to the infringement. ${ }^{118}$ Conversely, a full account of profits, due to intentional appropriation, was awarded in Peter Pan Manufacturing Corporation v Corsets Silhouette Ltd. ${ }^{119}$

It is therefore surprising that in Novoship this was not raised in the judgment and the proportionality principle was treated only as relevant to liability: 'One ground on which the court may withhold the remedy is that an account of profits would be disproportionate

110 One of the terms used in Monarch Steamship (n 98) 227.

111 Novoship (n 2) [119].

112 Walsh v Shanahan [2013] EWCA Civ 411, [2013] 2 P\&CR DG7; Satnam Investments Ltd v Dunlop Heywood \& Co Ltd [1999] 3 All ER 652 (CA).

113 A-Gv Blake (n 3).

114 Novoship (n 2) [119]; see also [98]ff.

115 Fyffes Group Ltd v Templeman [2000] 2 Lloyd's Rep 643 (QB), $668 \mathrm{ff}$.

116 Ibid 672.

117 Section 4.c.

118 [1969] 1 WLR 809 (CA), 810.

119 [1964] 1 WLR 96 (Ch). 
in relation to the particular form and extent of wrongdoing.' 120 The consequence of this is so clear it needs no further argument: it is more likely to be disproportionate to disgorge if it is impossible to apportion.

This, it is submitted, is a significant cause of the difficulties in Novoship. Thinking it inappropriate or impossible to apportion the gain, the Court of Appeal, having starting out wanting at most a weaker prophylactic approach, decided that full disgorgement was disproportionate. This was a reasonable conclusion given this (incorrect, it is submitted), premise. But the result is that the tests were construed so generously that they have steered the law far away from the justification the court posited, namely that liability exists to deter breach of fiduciary duty and its assistance.

\section{5.e NOVOSHIP'S DISINTEREST IN THE OPPORTUNITY}

That deals with the general aspect of the proportionality test. That test, however, was also given a specific aspect: it would be disproportionate to disgorge because the opportunity was one Novoship had actively foregone. Since Novoship was content to lay off the risk, in effect it had disavowed any interest in any consequent profits, and hence the company had lost nothing. Although Novoship would not have let vessels to Nikitin had the company known of the wrongdoing, it would certainly have let to someone else. ${ }^{121}$

This point was only explored by the Court of Appeal summarily and, once again, a closer look reveals factors that were overlooked. The court said that:

In our judgment [this gain] cannot be described as profits which ought to have been made for the beneficiary, and therefore they fall outside the rationale for the ordering of an account. ${ }^{122}$

This is one rationale for disgorgement against fiduciaries, indeed, the one Lionel Smith advances. That is fine as far as it goes. But that does not mean that it is the only rationale for disgorgement, otherwise there could be no disgorgement in the intellectual property and confidential information cases. Furthermore, a suitable rationale was given by the Court of Appeal in the instant case: the deterrence of the assistance of fiduciary infidelity.

This abrupt change in justification further suggests that the deterrence of wrongdoing was not a weighty factor in the tests adopted, despite what was said about it. What appeared to matter instead is whether the principal lost an opportunity. This, again, indicates a non-prophylactic approach - looking to the principal's loss, where a prophylactic approach would ignore this and instead look only to the wrongdoer's gain.

Nonetheless, there simply must be something in the Court of Appeal's claim that the purpose of the jurisdiction is to deter fiduciary wrongdoing and also its assistance. If so, there may be a difference where the dishonest assistant procures, rather than merely assists, the underlying breach of fiduciary duty, as Ridge suggests. ${ }^{123}$ It might further be thought that the dishonest assistant should be excused if the fiduciary would have found a way to execute his or her scheme without the need for this particular dishonest assistant's help. The overall justification is that disgorging from the mere assistant would have no deterrent effect in these circumstances and the remedy is therefore not warranted.

It therefore pays to look in more detail at what Nikitin did in the course of the two transactions and how they were linked. The trial judge was unable to determine the

120 Novoship (n 2) [119] (emphasis added).

121 Ibid [9], [117].

122 Ibid [117].

123 See text to $n 31$ above. 
precise connection between the two transactions. Speaking from the vantage point of the PDVSA transaction, he was, however, 'satisfied' that it must have been one of three things and probably the first or the last of them:

(i) Mr Nikitin provided or held out the prospect of some other benefit to $\mathrm{Mr}$ Mikhaylyuk; or

(ii) made, or constituted, some threat to him, or put him under some pressure, which, in either case, resulted in Mr Mikhaylyuk getting Mr Ruperti to make these payments; or whether, on the other hand

(iii) Mr Mikhaylyuk was seeking to benefit Mr Nikitin because of some advantage that he thought to gain thereby, either in the form of a deal or otherwise. ${ }^{124}$

In all three eventualities, there is a degree of active participation as opposed to merely providing professional services for a fee. These eventualities also suggest that there is a continuum of participation and it is not simply a binary choice between procurement and mere assistance. While not all of them go so far as to say that Nikitin masterminded both transactions, the culpability they disclose is far stronger than the familiar cases where dishonest assistants have not been fully cognisant of the underlying wrongdoing. ${ }^{25}$ What is clear is that Nikitin was not merely assisting. Furthermore, even if there was no imperative to deter the particular fiduciary breach (and its assistance) in the Henriot transaction directly - where Novoship was not interested in the opportunity - there was an imperative to deter the other fiduciary breach. To do so, one must deter the Henriot transaction because of the link. One must ignore the objection that Nikitin did not intercept a wanted opportunity.

While the Court of Appeal reproduced the judge's finding of fact quoted above, ${ }^{126}$ it went no further into the distinction between mere assistance and what is tantamount to procurement, nor what would be necessary to amount to effective deterrence. ${ }^{127}$ Again, this shows the Court of Appeal's approach was non-prophylactic.

\section{5.f RESTRICTION TO THE HYPOTHETICAL BARGAIN MEASURE}

One corollary of all this was also unexplored in the judgment in Novoship. It has been made so difficult - if not impossible - on the 'effective causation' test to disgorge profits arising from independent enterprises that the action is de facto limited to the Wrotham Park hypothetical bargain measure. This is what was awarded in the only accessories case so far that has come near to awarding something close to an account of profits: Fyffes Group Ltd $v$ Templeman. ${ }^{128}$

In this case, one Templeman, an employee of Fyffes and a fiduciary, was being bribed by a client, Seatrade. Seatrade was therefore a dishonest assistant of Templeman's breach of fiduciary duty. However, it was found that Fyffes would have contracted with Seatrade in any event - even if the fiduciary had not been dishonest - albeit on better terms. Toulson $\mathrm{J}$ therefore refused a full account of profits, restricting the claimant to compensation because "[i]nsofar as Seatrade made an "ordinary" profit element, it was not

124 Novoship (HC) (n 13) [389].

125 E.g. Twinsectra Ltd v Yardley [2002] UKHL 12, [2002] 2 AC 164; Barlow Clowes International Ltd v Eurotrust International Ltd [2005] UKPC 37, [2006] 1 WLR 1476.

126 Novoship (n 2) [7](v).

127 Cf the Australian courts' emphasis on the distinction: Farah Constructions Pty Ltd v Say-Dee Pty Ltd [2007] HCA 22, (2007) 230 CLR 89, [161]; Grimaldi v Chameleon Mining NL (No 2) [2012] FCAFC 6, (2012) 200 FCR 296, [243]ff.

128 Fyffes (n 115). 
caused by the bribery of $\mathrm{Mr}$ Templeman, but was profit for the provision of services for which there would have been a contract in any event'. ${ }^{29}$ The measure of compensation awarded was (as regards that particular head of claim) on the hypothetical basis of how a prudent and honest negotiator, rather than Templeman, would have contracted. Toulson $J$ held that full account of profits was available in principle, but not on these facts (particularly owing to the existence of a pre-existing profit-sharing agreement.)

What was awarded was in essence the Wrotham Park hypothetical bargain measure, named after the case of Wrotham Park Estate Co Ltd $v$ Parkside Homes Ltd. ${ }^{130}$ It is a partial account of profits representing what would have been agreed. In that case, a property developer had built more homes than it ought to in breach of a restrictive covenant. The beneficiary of the covenant would not have entered into a bargain releasing the developer from this restriction. Nonetheless, the beneficiary was given an award of what that bargain would have been had it been possible; a small percentage of the anticipated profits such a release would have yielded. ${ }^{131}$ The 'gain' disgorged was equivalent to the loss caused by the breach, meaning the failure to honour a hypothetical contract of release. Once it is accepted that one may look to such hypothetical circumstances, the measure is less controversial - being for lost profits from that hypothetical contract, which is a perfectly ordinary head of claim in contract. So, the argument goes, the award is not really account of profits at all. It is just compensation.

Then, just as compensation is the usual measure for breach of contract, it is the usual measure for dishonest assistance. In Fyffes $v$ Templeman the hypothetical bargain would have been a variation improving the rate in Fyffes' favour. The difference between the better rate and the rate actually obtained was the same numerically as Seatrade's additional profit and thus was equal to the full disgorgement measure. On the facts, Fyffes' loss was Templeman's gain.

Nonetheless, the two measures are conceptually distinct. ${ }^{132}$ Only the full disgorgement measure gives access to profits such as those Nikitin made, because they do not relate to the immediate wrongdoing but consequent activity, unlike in Fyffes or Wrotham Park. That consequent activity is always predominantly caused by the wrongdoer or at least attributable predominantly to external causes and not the wrongdoing. This will be the case whether the opportunity was one the principal desired or not. It is therefore always beyond the reach of the test adopted, 'effective causation', as currently construed. Consequently, on the current law, the measure for account of profits for dishonest assistance is limited to the hypothetical bargain measure in practice.

\section{Solving the market movements problem}

It is submitted that, given the foregoing, a true disgorgement remedy should have been imposed, at least on the grounds that Nikitin had procured the scheme and perhaps on the grounds that even the mere assistance of a breach of fiduciary duty should be deterred by such a remedy. This is what the prophylactic approach requires. Any proportionality requirement should extend to quantum for the reasons set out above. On the strictest prophylactic approach, full disgorgement should have been imposed, but on

129 Ibid 672.

130 Wrotham Park (n 5).

131 Ibid 815.

132 The argument that the loss and gain measures are the same in these circumstances is also made in Ralph Cunnington, 'The Assessment of Gain-based Damages for Breach of Contract' (2008) 71 Modern Law Review 559. See generally Edelman (n 3) 2-3 and ch 3 as to the distinction. 
a less strict prophylactic approach - perhaps justified by the distance of the accessory from the fiduciary relationship - apportionment may be appropriate.

This demands an answer to the question of how the courts should apportion such that disgorgement is not disproportionate or to take what was not effectively caused by the wrongdoer. To recapitulate: the bulk of Nikitin's gain was, at least numerically, caused by the rise in the market. If disgorgement of his profits is not to be disproportionate, a way to split this cause in two must be found. The difficulty is, however, that there is no obviously applicable principle upon which to apportion.

Birks' and Virgo's proposals for remoteness of gains tests offer no assistance here. Edelman's proposal has more potential. ${ }^{133}$ However, even if Nikitin was taken not to have acted deliberately or cynically, the test would still not have apportioned his gain. The difficulty is that market movements are eminently foreseeable - move, put bluntly, is what markets do. ${ }^{134}$ Therefore a foreseeability of kind rule would do nothing to divide the market movements into recoverable and non-recoverable portions.

However, foreseeability of kind is not the only foreseeability test. For contractual remoteness of loss, there is a superadded requirement that the kind of loss be 'not unlikely' to occur. ${ }^{135}$ This is a way of raising the bar to recovery. This requirement is of no assistance to the issue of market movements because it is most likely that they will occur. ${ }^{136}$ It does show, however, that the foreseeability test has been modified where necessary, in this case to narrow it. There is no reason why the test could not be widened in different circumstances.

While in remoteness of loss cases there is no need for the extent of the loss to be foreseeable in England ${ }^{137}$ (in Australia there is authority suggesting the opposite), ${ }^{138}$ there is no reason why foreseeability of extent ought not to be part of the test for cutoff in gain cases. As Barker notes, the underlying justifications are different. ${ }^{139}$ Conversely, there are good reasons why it ought to be. If there is to be an allowance on the prophylactic approach - allowing a defendant like Nikitin to be rewarded only for his efforts and not for gains not attributable to those efforts - it is logical to allow only the value of what could have been foreseen. The gains attributable to the extraordinary and unforeseeable market movements would then have gone to the claimant. Nikitin's allowance would indeed have been in the lower reaches and consistent with the principle of prophylaxis.

There is some judicial support for this proposition. In the US case of Primean $v$ Granfield, Learned Hand J considered the matter of account of profits for the misappropriation of a claimant's money into a mining venture. ${ }^{140}$ One concern was the correct apportionment. The minerals could be traced into and were therefore clearly subject to the claim. The difficulty was the value created by their discovery and how much that was due to the defendant's own efforts. Some was due to the investment and skill put in to discover them. But clearly not all was - there was some value in the minerals' very

133 See section 4.c.

134 E.g. Koufos v C Czarnikow Ltd (The Heron II) [1969] 1 AC 350 (HL); The Achilleas (n 85).

135 The most popular formulation of the nebulous probability requirement from The Heron II (n 134) $388,406$.

136 Ibid 388, 406, 410.

137 Jackson v Royal Bank of Scotland [2005] UKHL 3, [2005] 1 WLR 377.

138 Burns v MAN Automotive Pty Ltd [1986] HCA 81, (1986) 161 CLR 653, 668, according to Wilson, Deane and Dawson JJ; Gibbs CJ and Brennan J treated the issue as one of mitigation.

139 See text to $\mathrm{n} 89$.

140184 F 480 (1911) (SDNY). See the discussion of it in Grimaldi (n 127) [541]ff. 
existence too, because such endeavours involve elements of risk and chance. Learned Hand J eschewed 'such metaphysics to ascertain how much such expenses contributed to the ore'. ${ }^{141}$ Other figures - the payments to obtain the lease, to open the mine, to work it and, crucially, the royalties paid - amounted to a proxy for that impossible question. Considering the deal that would have been made by reasonable parties would lead to the answer.

Transferred to the facts of Novoship, these principles from Primeau $v$ Granfield can be restated mutatis mutandis. Nikitin took a risk and was rewarded when it paid off. But some of that reward can be put down to his skill and effort and expected gain, and the rest down to a windfall caused by the luck and chance element within 'Nikitin's accurate or fortunate forecast', 142 to quote the trial judge, of the unforeseeably large market movements. On a practical basis this might be calculated with reference to long-term risk forecasts and historic average profits. This would allow such defendants to keep the average or expected gain while disgorging exceptional gains, yielding a parsimonious and just allowance.

Such apportionment would not, as a matter of definition, be disproportionate. Quite the opposite: one would apply the proportionality requirement to quantification rather than look at quantum and ask whether it was proportionate to disgorge the full amount. Moreover, the disgorged gain would also not be effectively caused by the defendant's own efforts, whereas the retained gain would. The difference is that in this proposal 'effective causation' is also construed as an apportioning principle rather than merely a test for liability. Moreover, it is supported by norms directly linked to the underlying and espoused policy of the law, which makes it possible to apply accurately. Clearly, there is a difficulty with precision - the outcome will be fairly uncertain - but the courts accept that it is impossible to be perfectly precise in such cases and what is required is 'not . . . mathematical exactness but only a reasonable approximation'. ${ }^{143}$

Finally, it is important to emphasise that this proposal requires that the principal actively foregoes the opportunity, as in Novoship. Had the dishonest assistant misappropriated an opportunity the principal desired, the answer is simpler. Interception should always justify a full account of profits.

\section{Conclusion}

In the first case to consider at length full disgorgement against a dishonest assistant, Novoship (UK) Ltd v Mikhaylyuk, the Court of Appeal adopted a considerably more generous approach than the traditional equitable one. Turning the equitable principle on its head, it sought to leave the wrongdoer with what was not due to the wrongdoing rather than to take all but that not due to the wrongdoing. It gave precedence to the fact that the principal lost nothing. As for the former, the difference may appear slight, even semantic, but it is not. The court considered that gains caused by neutral factors such as market movements were not due to the wrongdoing and thus left them with the wrongdoer. The deterrent effect is therefore much reduced and the approach cannot be called prophylactic. As for the latter, this is also a non-prophylactic approach because prophylactic remedies do not require loss to be suffered.

141 Quoted in Grimaldi (n 127) [543].

142 Novoship (HC) (n 13) [501] (emphasis added).

143 Warman v Dwyer (n 22) 558, quoted in Murad v Al-Saraj (n 22) [149] and My Kinda Town Ltd v Soll [1982] FSR 147 (Ch), 159. 
While worryingly generous to those who assist breaches of fiduciary duty, this would at least be coherent when one considers that dishonest assistants and knowing recipients are not fiduciaries and this may justify treating them more leniently. But it conflicts with the court's claim that the jurisdiction to disgorge exists to deter fiduciary wrongdoing and its assistance. The generosity of the allowance and the way the tests were construed are not consistent with this justification. This inconsistency endangers the coherent application and development of the law. If in precedents the decisions point one way but the justifications another, it will be impossible to predict the outcomes of claims where the facts are novel. The courts should take one position or the other and stick to it. Either the justification is not prophylaxis and deterrence and the outcome of Novoship is right, or the justification is prophylaxis and the outcome is wrong.

The root cause of this, it is suggested, was a lack of consideration of the normative underpinnings of the terms 'causation' and 'proportionality'. Treating them as formulae to be applied in isolation from their underpinnings has led to this incoherence. Accordingly, it is suggested that criticism of the adoption of the terms of causation and remoteness as alien to equity is beside the point. These terms do carry some helpful directions as to what the courts are looking to - provided they are defined adequately and not detached from their norms. Unfortunately, this was not the case in Novoship.

Perhaps most troubling of all, the primary test adopted for disgorgement, 'effective causation', has been construed so narrowly as to seemingly make it impossible to disgorge anything beyond the Wrotham Park hypothetical bargain measure in all but the rarest of cases, if indeed at all. This cannot have been intended. It is therefore hoped that, in time, the courts will revisit these issues and resolve them. 